Southern Illinois University Carbondale

OpenSIUC

Publications

Fisheries and Illinois Aquaculture Center

$4-1982$

\title{
The Cyclic Stocking of Parentals in a Farm Pond to Produce a Population of Male Bluegill x Female Green Sunfish $\mathrm{F}_{1}$ Hybrids and Male Redear Sunfish x Female Green Sunfish F 1 Hybrids
}

Kenneth F. Kurzawski

Roy C. Heidinger

Southern Illinois University Carbondale

Follow this and additional works at: http://opensiuc.lib.siu.edu/fiaq pubs

(c) by the American Fisheries Society 1982

Published in North American Journal of Fisheries Management, Vol. 2, Issue 2 (April 1982) at doi: 10.1577/1548-8659(1982)2<188:TCSOPI >2.0.CO;2

\section{Recommended Citation}

Kurzawski, Kenneth F. and Heidinger, Roy C. "The Cyclic Stocking of Parentals in a Farm Pond to Produce a Population of Male Bluegill x Female Green Sunfish $F_{1}$ Hybrids and Male Redear Sunfish x Female Green Sunfish F 1 Hybrids." (Apr 1982).

This Article is brought to you for free and open access by the Fisheries and Illinois Aquaculture Center at OpenSIUC. It has been accepted for inclusion in Publications by an authorized administrator of OpenSIUC. For more information, please contact opensiuc@lib.siu.edu. 


\title{
The Cyclic Stocking of Parentals in a Farm Pond to Produce a Population of Male Bluegill $\times$ Female Green Sunfish $F_{1}$ Hybrids and Male Redear Sunfish $\times$ Female Green Sunfish $F_{1}$ Hybrids
}

\author{
Kenneth F. Kurzawski' and Roy C. Heidinger \\ Fisheries Research Laboratory and Department of Zoology \\ Southern Illinois University, Carbondale, Illinois 62901
}

\begin{abstract}
A population of male bluegill (Lepomis macrochirus) $\times$ female green sunfish (Lepomis cyanellus) $F_{1}$ hybrids was established by parental stocking in a southern Ilinois farm pond containing male redear sunfish (Lepomis microlophus) $\times$ female green sunfish $F_{1}$ hybrids and largemouth bass (Micropterus salmoides). In 1967, male redear sunfish and female green sunfish parentals, along with fingerling bass, were stocked into a new farm pond. Nine years later in 1976, male bluegill and female green sunfish were stocked into the same pond. At the time of sampling in the fall of 1978, bluegill $\times$ green sunfish $F_{1}$ hybrids weighed an average of $3 \mathrm{~g}$ at annulus $\mathrm{I}, 24 \mathrm{~g}$ at annulus II, and 171 $\mathrm{g}$ at annulus III. Growth rates among the three year classes varied widely. The best growth was exhibited by the 1976 year class of bluegill $\times$ green sunfish $F_{1}$ hybrids. Redear $\times$ green sunfish $F_{1}$ hybrids sampled in 1969 weighed an average of $32 \mathrm{~g}$ at annulus $\mathrm{I}, 118 \mathrm{~g}$ at annulus $\mathrm{II}$, and $217 \mathrm{~g}$ at annulus III. Both $F_{1}$ hybrid sunfish crosses produced fish that reached the theoretical minimum harvestable size of $110 \mathrm{~g}$ at annulus III.
\end{abstract}

One area of pond management research in recent years has centered around stocking various sunfish hybrids in combination with largemouth bass (Micropterus salmoides) in lieu of the classical largemouth bass-bluegill (Lepomis macrochirus) combination (Childers and Bennett 1967; Heidinger and Lewis 1972; Henderson and Whiteside 1976; Ellison and Heidinger 1978). The reduced population fecundity due to a predominance of males exhibited by some hybrid sunfish (Ricker 1948; Childers 1967; Heidinger and Lewis 1972) allows the control of population densities, which is a primary consideration in the management of pond fish communities (Lewis and Heidinger 1978). Also, numerous studies have shown that the $F_{1}$ hybrid sunfish populations exhibit excellent growth (Krumholz 1950; Childers and Bennett 1967; Heidinger and Lewis 1972; Ellison and Heidinger 1978). Ellison and Heidinger (1978) found that even when hybrid sunfish were stocked in relatively infertile ponds, their growth still exceeded the average growth rate reported by Lopinot (1972) for bluegills in Illinois.

The hybrid sunfish-largemouth bass combi-

\footnotetext{
${ }^{1}$ Present address: Illinois Power Company, Clinton Power Station, East Route 54, Box 678, Clinton, Illinois 61727.
}

nation has shown promising results in a number of different environmental situations. Childers and Bennett (1967) produced exceptional fishing for both hybrid sunfish and largemouth bass in a 0.4-hectare farm pond. Heidinger and Lewis (1972) produced similar results in seven ponds with the redear sunfish (Lepomis microlophus) $\times$ green sunfish (Lepomis cyanellus) $\mathrm{F}_{1}$ hybrid $(\mathbf{R} \times \mathrm{G})$ and largemouth bass (the male parent is listed first). Ellison and Heidinger (1978) investigated stocking redear sunfish $\times$ green sunfish $F_{1}$ hybrids, bluegill $\times$ green sunfish $F_{1}$ hybrids $(B \times G)$, largemouth bass, and channel catfish (Ictalurus punctatus) in 33 southern Illinois ponds. A survey of pond owners involved in the study concluded that the majority favored the use of hybrid sunfish when stocked with largemouth bass.

At least some $F_{1}$ hybrid sunfish are highly vulnerable to angling (Childers and Bennett 1967; Henderson and Whiteside 1976). Childers (1967) reported that certain $F_{1}$ sunfish hybrids were so vulnerable to angling that fishermen in several lakes almost completely eliminated substantial $F_{1}$ hybrid sunfish populations in a few days of fishing. The aggressive behavior displayed by hybrid sunfish is the probable cause for the increased angling vulnerability. Because the $R \times G$ and $B \times G F_{1}$ hybrids occupy somewhat 
different feeding niches (for example, unlike the $\mathrm{B} \times \mathrm{G} \mathrm{F}_{1}$ hybrid, the $\mathrm{R} \times \mathrm{GF}_{1}$ hybrid will eat snails), it can be desirable to have both crosses in a pond.

Hybrid sunfish populations can be established in ponds by two methods. Parental fish of the correct sex can be stocked into clean ponds, or fingerling $F_{1}$ hybrid sunfish can be stocked directly into ponds. The use of fingerling hybrid sunfish requires restocking the pond with a large number of fingerlings on a regular basis. However, it is easy to adjust the densities of the various sunfish hybrids. In contrast, recruitment of $F_{1}$ hybrid sunfish from parental redear sunfish and green sunfish can take place for at least 4 years after the parentals are initially introduced (Heidinger and Lewis 1972). Attempts to simultaneously produce $R \times G$ and $B \times G F_{1}$ hybrids in the same pond by parental stocking have not been successful (Lewis and Heidinger 1978). The crosses always went in the direction of the parental redear sunfish. A cycle of different parental stockings over time could overcome this problem. If the male redear sunfish was used first, this cycle would have to provide enough time for complete mortality of the original male sunfish.

The objectives of the present study were to: (1) determine if the $B \times G F_{1}$ hybrid can be established by parental stocking under the pressure of an existing community of $R \times G F_{1}$ hybrids and largemouth bass; (2) compare the growth rates of the $B \times G F_{1}$ hybrid with the initial growth rates of the $R \times G F_{1}$ hybrid; and (3) determine the effect of introducing $\mathrm{B} \times \mathrm{G} \mathrm{F}_{1}$ hybrids on the growth rate of the existing largemouth bass population.

\section{Materials and Methods}

In 1967 , a population of $R \times G_{1}$ hybrids was established by stocking parental male redear sunfish and female green sunfish at the rate of six redear sunfish and four green sunfish per hectare in recently renovated Ogur's Pond (Heidinger and Lewis 1972). Fingerling largemouth bass were also stocked at this time. In the spring of 1976, after three consecutive years of no $F_{1}$ recruitment, but with $R \times G F_{1}$ hybrids and largemouth bass present, male bluegills and female green sunfish were stocked into the pond at the rate of 12 pairs per hectare.

Ogur's Pond, a 1.6-hectare pond located in Jackson County, Illinois, was sampled during
Table 1. Calculated weights (grams) corresponding to back calculated total lengths at each annulus of bluegill $\times$ green sunfish $F_{1}$ hybrids from Ogur's pond, fall 1978.

\begin{tabular}{lcrcc}
\hline & \multicolumn{5}{c}{$\begin{array}{c}\text { Calculated weight } \\
\text { at each annulus }\end{array}$} \\
Year class & $\begin{array}{c}\text { Num- } \\
\text { ber }\end{array}$ & \multicolumn{4}{c}{1} & 2 & 3 \\
\hline 1978 & 60 & 4.0 & & \\
1977 & 42 & 0.5 & 17.2 & 171.0 \\
1976 & 14 & 11.6 & 57.0 & 171.0 \\
Average weight & & 2.6 & 24.2 & $99.2-204.3$ \\
Range in weight & & $0.4-21.3$ & $10.0-112.6$ & 9 \\
\hline
\end{tabular}

the fall of 1978. The main objective of the sampling was to collect $B \times G_{1}$ hybrids for growth analysis. The status of other pertinent species in the pond (largemouth bass, remaining $R \times G$ $F_{1}$ or $F_{2}$ hybrids, parental bluegill and green sunfish, and any contaminating sunfish) also was noted.

Electrofishing, gillnetting, trapnetting, and shoreline seining were used to sample fish from the pond. Data taken from each fish collected included species, total length, and weight. Also, a scale sample was taken from the left side of each fish just below the lateral line at the point where the tip of the pectoral fin touches the body when pressed against the side of the fish. Scale impressions were made on acetate slides and read with a scale projector at $29 \times$. The direct proportion method with a Fraser correction of $20 \mathrm{~mm}\left(\mathrm{R}^{2}=0.97661\right)$ was used to calculate length at each annulus.

A length-weight relationship was used to calculate the average weight at each annulus from the average calculated total length at each annulus. The relationship calculated for $\mathrm{B} \times \mathrm{G} \mathrm{F}_{1}$ hybrids was: $\log _{10} W=-5.60924+3.39831$ $\left(\log _{10} T L\right) ;\left(R^{2}=0.99303\right)$.

\section{RESULTS}

Three year classes of $\mathrm{B} \times \mathrm{G} \mathrm{F}_{1}$ hybrids were collected from Ogur's Pond in the fall of 1978. These hybrid sunfish were produced from parental male bluegill and female green sunfish that were stocked in the spring of 1976 . Twenty-four largemouth bass and two parental green sunfish also were collected. No $F_{2}$ hybrid sunfish or remnants of the $R \times G F_{1}$ hybrid population established in 1967 were evident in the pond at the time of sampling. 
Table 2. Back-calculated total lengths (millimeters) of bluegill $\times$ green sunfish $F_{1}$ hybrids from Ogur's pond, fall 1978.

\begin{tabular}{lcccc}
\hline & \multirow{4}{*}{$\begin{array}{c}\text { Num- } \\
\text { Year class }\end{array}$} & \multicolumn{4}{c}{ beral length at each annulus } \\
\cline { 3 - 5 } & 60 & 1 & 2 & 3 \\
\hline 1978 & 67.2 & & \\
1977 & 42 & 36.4 & 103.3 & \\
1976 & 14 & 92.0 & 147.0 & 203.1 \\
Average length & & 59.1 & 114.2 & 203.1 \\
Range in length & $32.8-110.5$ & $88.0-176.6$ & $173.0-214.0$ \\
\hline
\end{tabular}

The initial year class (1976) of $B \times G F_{1}$ hybrids exhibited the most rapid growth rates of the three year classes present at the time of sampling (Tables 1 and 2). At Annulus I, the 1976 year class attained an average weight of $11.6 \mathrm{~g}$ (Table 1). This compares with an average weight at Annulus I of $4.0 \mathrm{~g}$ for the 1978 year class and $0.5 \mathrm{~g}$ for the 1977 year class. At Annulus II, there is again a marked disparity in growth between the 1976 and 1977 year classes of $F_{1}$ hybrid sunfish. The 1976 year class reached an average weight of $57.0 \mathrm{~g}$, while the 1977 year class averaged only $17.2 \mathrm{~g}$ at Annulus II. At Annulus III, the 1976 year class of $B \times G F_{1}$ hybrids weighed an average of $171.0 \mathrm{~g}$. The average growth increment from Annulus II to Annulus III for these fish was $114 \mathrm{~g}$. This corresponds to a two-fold increase in the average weight attained at Annulus II. The average total length increased by just over one-half (147-203 mm) during the same period (Table 2).

The average growth rates of $\mathrm{B} \times \mathrm{GF}_{1}$ hybrids in Ogur's Pond were compared with other growth data on hybrid sunfish (Table 3). An important comparison can be made with the $R \times G$ $F_{1}$ hybrids, which had the advantage of exploiting a recently renovated pond, collected from Ogur's Pond by Heidinger and Lewis (1972). The $R \times G F_{1}$ hybrids weighed more, on the average, at Annuli I-III than did B $\times G F_{1}$ hybrids from the same pond. Both combinations of parental sunfish produced $F_{1}$ hybrids that easily attained the suggested minimum harvestable size of $110 \mathrm{~g}$ (Ellison and Heidinger 1978) during their third growing season. The 1976 year class of $B \times G F_{1}$ hybrids accounted for the harvestable-size fish (Table 1). Subsequent year classes of $B \times G F_{1}$ hybrids probably did not reach 110 $g$ until their fourth year of growth. However, even this growth rate would still exceed the average growth rate of bluegill in Illinois (Lopinot 1972).

Also included in Table 3 are growth data obtained in other studies on sunfish hybrids. The $\mathrm{R} \times \mathrm{G} \mathrm{F}_{1}$ hybrids stocked as fingerlings (Heidinger and Lewis 1972) averaged heavier weights at each annulus than did $B \times G$ or $\mathrm{R} \times \mathrm{G} \mathrm{F}_{\mathbf{1}}$ hybrids produced by parental stocking. This increase in growth rate probably was due to the lower population density of fish in the ponds stocked with fingerling hybrid sunfish.

Table 3. Mean weights (grams) at age for bluegill $\times$ green sunfish $(B \times G)$ and redear sunfish $\times$ green sunfish $(R \times G) F_{1}$ hybrids in southern Illinois ponds.

\begin{tabular}{|c|c|c|c|c|c|c|c|c|c|c|c|}
\hline \multirow[b]{3}{*}{ Type } & \multirow{3}{*}{$\begin{array}{l}\text { Num- } \\
\text { ber of } \\
\text { ponds }\end{array}$} & \multirow{3}{*}{$\begin{array}{l}\text { Stock- } \\
\text { ing } \\
\text { method }\end{array}$} & \multicolumn{8}{|c|}{ Mean weight at each annulus } & \multirow[b]{3}{*}{ Citation } \\
\hline & & & \multicolumn{2}{|c|}{1} & \multicolumn{2}{|c|}{2} & \multicolumn{2}{|c|}{3} & \multicolumn{2}{|c|}{4} & \\
\hline & & & Weight & Number & Weight & Number & Weight & Number & Weight & $\begin{array}{c}\text { Num- } \\
\text { ber }\end{array}$ & \\
\hline$B \times G$ & 1 & $\mathbf{P}^{\mathbf{a}}$ & 2.6 & 116 & 24.2 & 56 & 171.0 & 14 & & & Present study \\
\hline $\mathbf{R} \times \mathbf{G}$ & 1 & $\mathbf{P}^{b}$ & 31.6 & 378 & 118.0 & 79 & 217.0 & 45 & & & $\begin{array}{l}\text { Heidinger and } \\
\text { Lewis (1972) }\end{array}$ \\
\hline $\mathbf{R} \times \mathbf{G}$ & 3 & $\mathbf{F}^{\mathbf{c}}$ & 37.9 & 140 & 121.1 & 86 & 286.0 & 61 & 636.6 & 18 & $\begin{array}{l}\text { Heidinger and } \\
\text { Lewis (1972) }\end{array}$ \\
\hline $\mathbf{R} \times \mathbf{G}$ & 14 & $\mathbf{F}$ & 3.0 & 31 & 46.0 & 31 & 91.0 & 31 & 127.0 & 6 & $\begin{array}{l}\text { Ellison and } \\
\text { Heidinger (1978) }\end{array}$ \\
\hline$B \times G$ & 28 & $\mathbf{F}$ & 6.0 & 122 & 45.0 & 122 & 92.0 & 122 & 148.0 & 21 & $\begin{array}{l}\text { Ellison and } \\
\text { Heidinger (1978) }\end{array}$ \\
\hline
\end{tabular}

a $\mathbf{P}=$ Parentals

b $\mathbf{P}=$ Parentals stocked in Ogur's pond in 1967.

c $\mathbf{F}=$ Fingerlings. 
Ellison and Heidinger (1978) investigated the growth of both $R \times G$ and $B \times G F_{1}$ hybrids established by fingerling stocking in infertile southern Illinois ponds similar to Ogur's Pond (Table 3 ). The fingerling $F_{1}$ hybrid sunfish were stocked in ponds with different combinations of channel catfish and largemouth bass. In this instance, the $B \times G F_{1}$ hybrids produced by parental stocking in Ogur's Pond grew better than the $F_{1}$ hybrid sunfish that were stocked as fingerlings.

\section{MANAgEMENT IMPLICATIONS}

The most important objective of this study was to determine if cyclic stocking of selected parental sunfish is a feasible method to establish a catchable population of $F_{1}$ hybrid sunfish. The presence of harvestable-size, 3-year-old $B \times G$ $F_{1}$ hybrids in Ogur's Pond indicated that this is a viable pond-stocking technique. Although at the time of sampling very little angling for hybrid sunfish was done, the potential for desirable fishing was present. In addition, a qualitative appraisal of the largemouth bass population indicated that the hybrid sunfish-largemouth bass combination was beneficial to largemouth bass growth. The largemouth bass also eliminated any $F_{2}$ hybrid sunfish that may have been produced. Numerous other studies have indicated that $F_{2}$ hybrid sunfish are rare or nonexistent in the presence of largemouth bass (Childers and Bennett 1967; Heidinger and Lewis 1972; Ellison and Heidinger 1978).

Numerous factors combined to produce the variable growth exhibited among the three year classes of $\mathrm{B} \times \mathrm{G} \mathrm{F}_{1}$ hybrids. In Ogur's Pond, some of these factors were: the density of the remaining $B \times G F_{1}$ hybrids, availability of food, strength of each year class of $B \times G F_{1}$ hybrids, and predation by largemouth bass. A low density of $B \times G F_{1}$ hybrids present in 1976 when $B \times G F_{1}$ hybrids were first produced resulted in excellent growth for the 1976 year class of $B \times G F_{1}$ hybrids. Heidinger and Lewis (1972) also found that $F_{1}$ hybrid sunfish spawned in the first year after stocking usually exhibited better growth than subsequent year classes.

The size a fish attains in the first year of its life is instrumental in determining growth in subsequent years. A rapid initial growth rate would enable a fish to prey upon a wider range of food organisms, and, in turn, be less vulnerable to predation. This would seem to apply to hybrid sunfish, which possess the genetic potential for excellent growth. The rapid growth rate of the 1976 year class of $B \times G_{1}$ hybrids could have been influenced positively by this factor, while the slow-growing 1977 year class could have been influenced negatively.

An important consideration in the cyclic stocking of parental sunfish is the duration of the restocking cycle. If a pond owner wanted to maintain a hybrid sunfish population of the same cross, a 3- to 5-year-cycle of parental sunfish stocking would be appropriate. If the management goal is to have both the $R \times G$ and $B \times G$ $F_{1}$ hybrids in the pond at the same time, a more complicated stocking scenario would be necessary. In a new or renovated pond, one would initially stock the parentals for the $B \times G F_{1}$ cross in the spring. During the second year, after the second year class had been produced, the male redear sunfish would be added. Complete mortality of parental sunfish would probably occur in 3-5 years after the male redear sunfish were stocked. A significant number of $F_{1}$ hybrid sunfish should still be present at this time. If another 1-2 years passed before stocking the new pairs of male bluegill and female green sunfish, growth of the new $B \times G_{1}$ hybrid sunfish would be improved due to lower fish population density in the pond. The cycle then would be started over again. A cycle of $7-8$ years seems optimal. The second stocking in Ogur's Pond took place 11 years after the first stocking.

A pond owner would have to weigh the advantages of cyclic stocking of parental sunfish vs. the stocking of fingerling hybrid sunfish. The most obvious benefit of cyclic stocking of parental sunfish would be the low cost and ease of maintaining a harvestable population of $F_{1}$ hybrid sunfish. In most cases, maximum growth of these hybrid sunfish would not be as great as that of hybrid sunfish from fingerling stocking, but harvestable fish would be produced by both methods in approximately the same length of time.

Even though this study was limited to one pond, the results have demonstrated the potential of cyclic stocking of different pairs of parental sunfish in pond management. In certain pond situations, this technique should provide good fishing for both $F_{1}$ hybrid sunfish and largemouth bass over a longer period than had been possible with other pond-stocking methods. It removes 
the periodic need for renovation of the pond, which is costly both in terms of money and time.

\section{REFERENCES}

Childers, W. F. 1967. Hybridization of four species of sunfishes (Centrarchidae). Illinois Natural History Survey Bulletin 29(3): 159-214.

Childers, W. F., and G. W. BenNett. 1967. Hookand-line yield of largemouth bass and redear $\times$ green sunfish hybrids in a one-acre pond. The Progressive Fish-Culturist 29(1):27-35.

Ellison, D. G., ANd R. C. Heidinger. 1978. Dynamics of hybrid sunfish in southern Illinois farm ponds. Proceedings 30th Annual Conference Southeastern Association Fish and Wildlife Agencies 30(1976):82-87.

Heidinger, R. C., ANd W. M. Lewis. 1972. Potentials of the redear sunfish $\times$ green sunfish hybrid in pond management. The Progressive Fish-Culturist 34(2): 107-109.
Henderson, E. B., and B. G. Whiteside. 1976. Population dynamics of the green sunfish male $\times$ redear sunfish female hybrid as compared with its reciprocal cross and parental species. Proceedings 29th Annual Conference Southeastern Association Game and Fish Commissioners 29(1975):273-278.

KrUMHOLz, L. A. 1950. Further observations on the use of hybrid sunfish in stocking small ponds. Transactions of the American Fisheries Society 49:112-124.

Lewis, W. M., ANd R. C. Heidinger. 1978. Tailormade fish populations for small lakes. Southern Illinois University, Fisheries Research Bulletin 5, Carbondale, Illinois, USA.

LopINot, A. C. 1972. Pond fish and fishing in Illinois. Fisheries Bulletin 5. Illinois Department of Conservation, Springfield, Illinois, USA.

RICKER, W. C. 1948. Hybrid sunfish for stocking small ponds. Transactions of the American Fisheries Society 75:84-96. 